\title{
Different inhibitory actions of IGFBP-1, -2 and -4 on IGF-I effects in vascular smooth muscle cells
}

\author{
T Gustafsson, P Andersson and $\mathbf{H}$ J Arnqvist
}

Department of Biomedicine and Surgery, Division of Cell Biology, Faculty of Health Sciences, Linköping University, Linköping, Sweden

(Requests for offprints should be addressed to T Gustafsson, Department of Biomedicine and Surgery, Division of Cell Biology, Faculty of Health Sciences, Linköping University, S-581 85 Linköping, Sweden)

\begin{abstract}
IGF-I is involved in the regulation of metabolism, growth and migration of vascular smooth muscle cells (VSMCs). We have studied how IGFBP-1, -2 and -4 modulate IGF-I-induced DNA and protein synthesis in cultured rat VSMCs. DNA and protein synthesis were measured as incorporation of $\left[{ }^{3} \mathrm{H}\right]$ thymidine and $\left[{ }^{3} \mathrm{H}\right]$ leucine into DNA and protein respectively. Western immunoblot was used to detect IGFBPs in conditioned medium and solution hybridization was used to measure IGFBP gene expression. IGF-I stimulated DNA synthesis with an $\mathrm{EC}_{50}$ of $44 \mathrm{pM}$, reaching a maximal effect at $1 \mathrm{nM}$. An IGF-I concentration of $1 \mathrm{nM}$ was subsequently used in the experiments with IGFBPs. IGFBP-1 and IGFBP-4 acted in an inhibitory manner on IGF-I-induced DNA synthesis with calculated $\mathrm{IC}_{50}$ values of $1.6 \mathrm{nM}$ and $6.2 \mathrm{nM}$
\end{abstract}

respectively. IGFBP-2 (16 $\mathrm{nM})$ also inhibited the growth response to IGF-I, but this effect could only be obtained if the two peptides were pre-incubated together for $2 \mathrm{~h}$ prior to addition to the cells. IGFBP-1, -2 and -4 inhibited IGF-I-induced protein synthesis in a similar way. Immunoblot of the incubation medium showed little degradation of IGFBP-2 and -4 for up to $24 \mathrm{~h}$. mRNA for IGFBP-2 and -4, but not for IGFBP-1 was detected in the VSMCs. Endogenous IGFBP-2 and -4 could be detected by immunoblot in the conditioned medium but only if it was concentrated. In conclusion, IGFBP-1, -2 and -4 , of which IGFBP-2 and -4 may be locally derived, act as inhibitors with different potencies on IGF-I effects in VSMCs.

Journal of Endocrinology (1999) 161, 245-253

\section{Introduction}

In the circulation and throughout the extracellular space, the insulin-like growth factors (IGF-I and IGF-II) are complexed to a group of high affinity IGF-binding proteins (IGFBPs) (Rechler \& Clemmons 1998). A minor part, less than $1 \%$ of the total IGF-I content, is unbound and only the free fraction is considered to be bioactive (Baxter 1994). So far, six different IGFBPs (1-6), which all share structural homology with each other, have been cloned and characterized (Shimasaki \& Ling 1991). Although the 3-dimensional structure of the IGFBPs is not fully solved, it is accepted that IGFBPs consist of two globular $\mathrm{N}$ - and C-domains, with an intermediate, nonhomologous domain connecting the other two (Spencer \& Chan 1995).

IGFBP-1, -2 and -3 have been reported both to inhibit and enhance IGF-I effects, depending on cell type and other factors (Cornell et al. 1986, DeMellow \& Baxter 1988, Bar et al. 1989, Camacho-Hubner et al. 1991, Gockerman et al. 1995). IGFBP-4 has been reported to inhibit IGF-Iinduced effects (Kiefer et al. 1992, Cohick et al. 1993), while studies on IGFBP-5 have shown stimulatory effects (Andress
\& Birnbaum 1992, Jones et al. 1993a). So far, little is known about IGFBP-6. IGF-independent effects have been described for IGFBP-1 and IGFBP-3 (Liu et al. 1992, Jones et al. 1993b, Oh et al. 1993a).

IGF-I is involved in the regulation of metabolism, growth and the migration of vascular smooth muscle cells (VSMCs) (Arnqvist et al. 1995, Delafontaine 1995). We have shown previously that gene expression of IGFBP-2 and IGFBP-4 is markedly increased in hypertrophied rat VSMCs in vivo (Chen et al. 1994, 1995). Fasting and diabetes also modulate the gene expression of IGFBP-2 and -4 in rat VSMCs in vivo (Chen \& Arnqvist 1994) and have pronounced effects on circulating levels of IGFBP-1 (Brismar et al. 1994). Inhibitory effects of IGFBP-2 and -4 on IGF-I-induced DNA synthesis have been reported in porcine VSMCs under serum-free conditions (Bourner et al. 1992, Cohick et al. 1993). If pre-incubated with IGF-I, IGFBP-1 has been found to inhibit IGF-I-induced DNA synthesis in rat VSMCs (Motani et al. 1995). In the present study, we wanted to investigate how IGFBP-1, -2 and -4 modulate the effects of IGF-I on DNA and protein synthesis in rat VSMCs and to characterize possible differences between them. 


\section{Materials and Methods}

\section{Isolation and culturing of VSMCs}

Rat vascular smooth muscle cells were isolated and cultured according to a modified method of Nilsson et al. (1983). Small pieces of the aortas were digested for $1 \mathrm{~h}$ in $0 \cdot 1 \%$ collagenase in Ham's F12 medium, at $37^{\circ} \mathrm{C}$ and then for $20 \mathrm{~h}$ in fresh collagenase/F12. The cell suspension was filtered through a nylon filter (pore size $48 \mu \mathrm{m}$ ) and the cells were then washed in F12 medium. The cells were transferred to a solution of the following composition: F12 medium, 10\% new-born calf serum $(\mathrm{pH}=7 \cdot 4), 50 \mu \mathrm{g} / \mathrm{ml}$ ascorbic acid, $2 \mu \mathrm{g} / \mathrm{ml}$ fungizone and $50 \mu \mathrm{g} / \mathrm{ml}$ gentamycin sulphate. Cells were plated in $75 \mathrm{~cm}^{2}$ culturing flasks and kept at $37{ }^{\circ} \mathrm{C}$ in a humidified atmosphere of $5 \%$ $\mathrm{CO}_{2}$ in air. The cells were harvested using a solution of trypsin $(0 \cdot 25 \%)$ and EDTA $(0 \cdot 02 \%)$ when passaged and the medium was changed twice a week. Cells from the second to the tenth generation were used throughout all experiments. The cells were characterized as smooth muscle cells by morphological criteria and with an antibody which recognizes a unique epitope of $\alpha$-smooth muscle actin (Skalli et al. 1986). All experiments were performed on confluent cell cultures, which were kept for $24 \mathrm{~h}$ in serum-free F12 medium before the experiments.

\section{DNA and protein synthesis}

DNA synthesis was quantified by measuring $\left[{ }^{3} \mathrm{H}\right]$ thymidine incorporation into DNA. The cells were grown in 96-well plates and incubated for $24 \mathrm{~h}$ in serum-free F12 medium, with the addition of $1 \mu \mathrm{Ci} / \mathrm{ml}\left[{ }^{3} \mathrm{H}\right]$ thymidine and in the presence or absence of IGF-I and/or IGFBPs at the indicated concentrations in fresh serum-free F12 medium. The cells were washed with F12 medium and DNA was precipitated with $5 \%$ ice-cold trichloroacetic acid (TCA). DNA was solubilized in $0.1 \mathrm{M} \mathrm{KOH}$. One hundred and seventy microliters of the solution (total $200 \mu \mathrm{l}$ ) in each well was added to scintillation liquid and the radioactivity was counted in a liquid scintillation counter. The data were presented as percentage change over control cells.

Protein synthesis was quantified by measuring $\left[{ }^{3} \mathrm{H}\right]$ leucine incorporation into protein. The cells were grown in 96-well plates and incubated for $20 \mathrm{~h}$ in serumfree F12 medium, in the presence or absence of IGF-I and/or IGFBPs at the indicated concentrations. $\left[{ }^{3} \mathrm{H}\right]$ Leucine was added in a final concentration of $1 \mu \mathrm{Ci} / \mathrm{ml}$ for the last $90 \mathrm{~min}$. The cells were rinsed with cold phosphate-buffered saline (PBS) $(\mathrm{pH}=7 \cdot 4)$ and protein was precipitated in ice-cold 5\% TCA. Protein was solubilized in a solution with the following composition: $5 \%$ sodium dodecyl sulphate (SDS), $20 \mathrm{mM} \mathrm{Na}_{2} \mathrm{CO}_{3}$ and $2 \mathrm{mM}$ EDTA. Radioactivity was counted and data were presented as described in the $\left[{ }^{3} \mathrm{H}\right]$ thymidine section above. $m R N A$ levels of IGFBP-1, -2 and -4

VSMCs were grown to confluence in Petri dishes and were then kept in serum-free F12 medium for $24 \mathrm{~h}$. Serum-free medium was changed and the cells were incubated for another $24 \mathrm{~h}$. The cells were then harvested in SET buffer (1\% SDS, $20 \mathrm{mM}$ Tris, $10 \mathrm{mM}$ EDTA, $\mathrm{pH}=7 \cdot 5$ ) and homogenized with a polytron. Proteinase K was added and the samples were extracted with phenol and chloroform according to the method of Durnam \& Palmiter (1983). Total nucleic acids were precipitated in 95\% ethanol. The DNA content was measured as described by Labarca \& Paigen (1980). The mRNA levels for IGFBP-1, -2 and -4 were analyzed with a solution hybridization assay using $\left[{ }^{35} \mathrm{~S}\right] \mathrm{UTP}-$ labeled RNA probes. The IGFBP-1 probe consisted of 407 bases of a rat cDNA clone. The IGFBP-2 probe consisted of 397 bases complementary to exons 2 and 3 and part of exon 4 of the IGFBP-2 gene. The probe for IGFBP-4 consisted of 444 bases of a rat cDNA clone. The probes were synthesized as described by Melton et al. (1984). The samples were hybridized with each probe for $18 \mathrm{~h}$ at $70^{\circ} \mathrm{C}$. The hybridization solution contained a total volume of $40 \mu \mathrm{l}$ $0.6 \mathrm{M} \mathrm{NaCl}, 20 \mathrm{mM}$ Tris, $4 \mathrm{mM}$ EDTA, $0.75 \mathrm{mM}$ dithiothreitol (DTT), 25\% formamide and $0 \cdot 1 \%$ SDS. At least 10000 c.p.m. of the $\left[{ }^{35}\right.$ S]UTP-labeled probe were used per sample. RNases were then added and the double stranded RNA was precipitated in $6 \mathrm{M}$ TCA. The hybrids were collected on filter and the radioactivity was counted in a liquid scintillation counter. In each assay, a standard curve was included. The curve was created by hybridizing known amounts of in vitro synthesized sense RNA with antisense (probe).

\section{Western blot analysis of IGFBPS}

The cells were grown to confluence in 96-well plates and were then starved in serum-free medium for $24 \mathrm{~h}$. Human recombinant IGFBP-2 and IGFBP-4 were added at the indicated concentrations and were incubated for $24 \mathrm{~h}$. Some wells included cells with no exogenous addition of IGFBPs, while others included IGFBP addition but no cells. Four nanograms human recombinant IGFBP were used as a positive control. The conditioned medium $(80 \mu \mathrm{l})$ was collected and $60 \mu \mathrm{l}$ sample buffer were added. Fifty microliters of this solution were applied onto a $15 \%$ SDS-PAGE. Proteins were transferred onto polyvinylidene difluoride (PVDF) membranes for $1 \mathrm{~h}(200 \mathrm{~mA})$ with transfer buffer (15 mM Tris, $120 \mathrm{mM}$ glycine, 5\% methanol, $\mathrm{pH}=8 \cdot 3)$. The sheets were saturated with $0 \cdot 2 \%$ polyvinyl alcohol dissolved in Tris-buffered saline (TBS)Tween (TBS-T; $0 \cdot 2 \%$ ), $\mathrm{pH}=7 \cdot 6$ (overnight at $4{ }^{\circ} \mathrm{C}$ ), and incubated for $1 \mathrm{~h}$ with polyclonal antibodies (1:3000) raised against bovine IGFBP-2 and human IGFBP-4. After washing 3 times (15 and $2 \times 5 \mathrm{~min}$ each) with TBS-T, a donkey anti-rabbit immunoglobulin G horseradish peroxidase-labeled antibody (1:3000) was added for 
$1 \mathrm{~h}$. After washing three times as described above, the detection was visualized by enhanced chemiluminescense (ECL) analysis with the Amersham ECL system using ECL Hyperfilms for exposure. In order to concentrate conditioned medium, VSMCs were grown in Petri dishes ( $7 \mathrm{ml}$ conditioned medium). Confluent VSMCs were starved for $24 \mathrm{~h}$ in serum-free F12 medium. After another $24 \mathrm{~h}$ incubation in fresh serum-free medium under similar conditions, the conditioned medium ( $5 \mathrm{ml} /$ dish) was collected. EDTA in a final concentration of $5 \mathrm{mM}$ was added to prevent protein degradation. The samples were immediately centrifuged to remove cells and other material in the medium. Fifty microliters $0 \cdot 1 \%$ BSA and $5 \mathrm{ml} 10 \%$ TCA were added to precipitate protein. The samples were incubated at $4{ }^{\circ} \mathrm{C}$ overnight and were then centrifuged at 11000 r.p.m. at $4{ }^{\circ} \mathrm{C}$ for $30 \mathrm{~min}$. The pellet was washed twice with 95\% ethanol and was then dissolved in $250 \mu \mathrm{l}$ electrode buffer. Forty microliters of the sample were mixed with $20 \mu \mathrm{l}$ sample buffer and then applied on $15 \%$ SDS-PAGE. The further steps were performed according to the scheme described in the section above.

\section{Chemicals}

$\left[{ }^{3} \mathrm{H}\right]$ Thymidine and $\left[{ }^{3} \mathrm{H}\right]$ leucine were from Amersham International (Amersham, Bucks, UK). Human recombinant IGF-I was obtained from Pharmacia Upjohn (Stockholm, Sweden), human recombinant IGFBP-2 and IGFBP-4 (from yeast) from Austral Biologicals (San Ramon, CA, USA). IGFBP-1 was a gift from Dr Mats Lake, Pharmacia Upjohn, Stockholm, Sweden. Trypsin was from Difco Labs (Detroit, MI, USA) and collagenase type I was from Sigma (St Louis, MO, USA). The monoclonal antibody against $\alpha$-smooth muscle actin was from Sigma Immuno Chemicals (La Jolla, CA, USA) and the polyclonal antibodies against IGFBP-2 and IGFBP-4 were from Upstate Biotechnology (Lake Placid, NY, USA) (see Bourner et al. 1992 and Camacho-Hubner et al. 1992). The source of both antibodies was rabbits immunized with bovine IGFBP-2 or human IGFBP-4 respectively. The antibodies detect human and rat IGFBP-2 and IGFBP-4. PVDF membranes were from Dupont (Boston, MA, USA) and scintillation liquid (Ultima Gold) was from Packard Instrument Company (Meriden, CT, USA). Chemicals and solutions for cell culture were received from GIBCO BRL Life Technologies (Täby, Sweden). Proteinase K was from Merck (Darmstadt, Germany) and the chemicals for antisense (probe) and sense synthesis were from Promega (Madison, WI, USA). RNase A, RNase T1 and herring sperm DNA were obtained from Boehringer (Mannheim, Germany). Phenol was from Fischer Scientific (Fair Lawn, NJ, USA).

\section{Statistics}

Values are given as means \pm S.E.M. Statistical comparisons for more than two groups were made according to

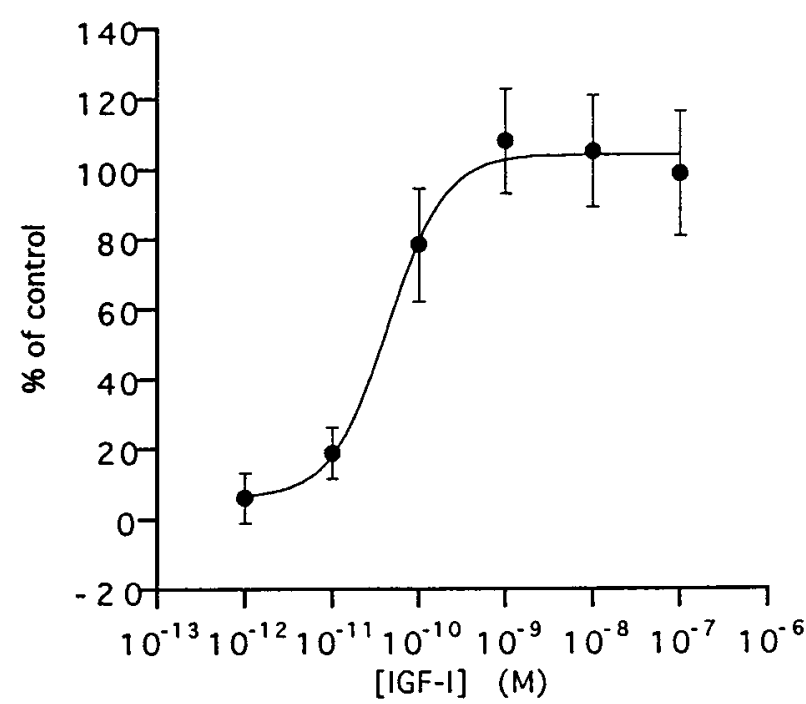

Figure 1 The effect of different concentrations of IGF-I on $\left[{ }^{3} \mathrm{H}\right]$ thymidine incorporation in rat vascular smooth muscle cells. Confluent cell cultures were incubated in F12 medium for $24 \mathrm{~h}$, in the presence of $\left[{ }^{3} \mathrm{H}\right]$ thymidine and without or with IGF-I at the indicated concentrations. Values are given as mean \pm S.E.M., $n=4$ and the samples were measured in triplicate.

ANOVA (Scheffé's test). Paired Student's $t$-test was used when comparing two dependent groups.

\section{Results}

IGFBP modulation of IGF-I-induced DNA and protein synthesis in VSMCs

IGF-I dose dependently stimulated DNA synthesis in VSMCs (Fig. 1). The $\mathrm{EC}_{50}$ value was $44 \mathrm{pM}(n=4)$. The maximum effect was reached at an IGF-I concentration of $1 \mathrm{nM}$ and this concentration was subsequently used in the experiments with IGFBPs.

IGFBP-1 in a concentration of $18 \mathrm{nM}(500 \mathrm{ng} / \mathrm{ml})$ significantly inhibited the effect of IGF-I on DNA synthesis (Fig. 2a). The calculated $\mathrm{IC}_{50}$ value for the inhibition was $1.6 \mathrm{nM}(n=5)$. IGF-I-induced protein synthesis was also inhibited by $18 \mathrm{nM}$ IGFBP-1 (Fig. 2b).

IGFBP-2 up to a concentration of $16 \mathrm{nM}(500 \mathrm{ng} / \mathrm{ml})$ did not inhibit significantly the IGF-I effect on DNA synthesis (Fig. 3a). When we performed experiments where IGF-I and IGFBP-2 were preincubated at $4{ }^{\circ} \mathrm{C}$ for $2 \mathrm{~h}$ prior to addition to the cells, IGFBP-2 at $16 \mathrm{nM}$ $(500 \mathrm{ng} / \mathrm{ml})$ was capable of significantly inhibiting the effect of IGF-I on VSMC growth (Fig. 3b). IGFBP-2 $(16 \mathrm{nM})$ also inhibited IGF-I-induced protein synthesis when the same pre-incubation procedure was used (Fig. 3c). The inhibitory effect of IGFBP-4 on IGF-Iinduced DNA synthesis was more modest than that of IGFBP-1 (Fig. 4a). The inhibition was significant at 


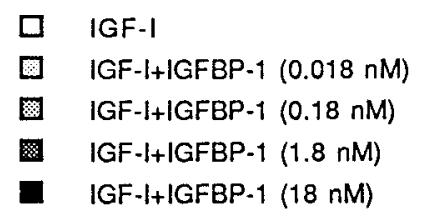

(a)
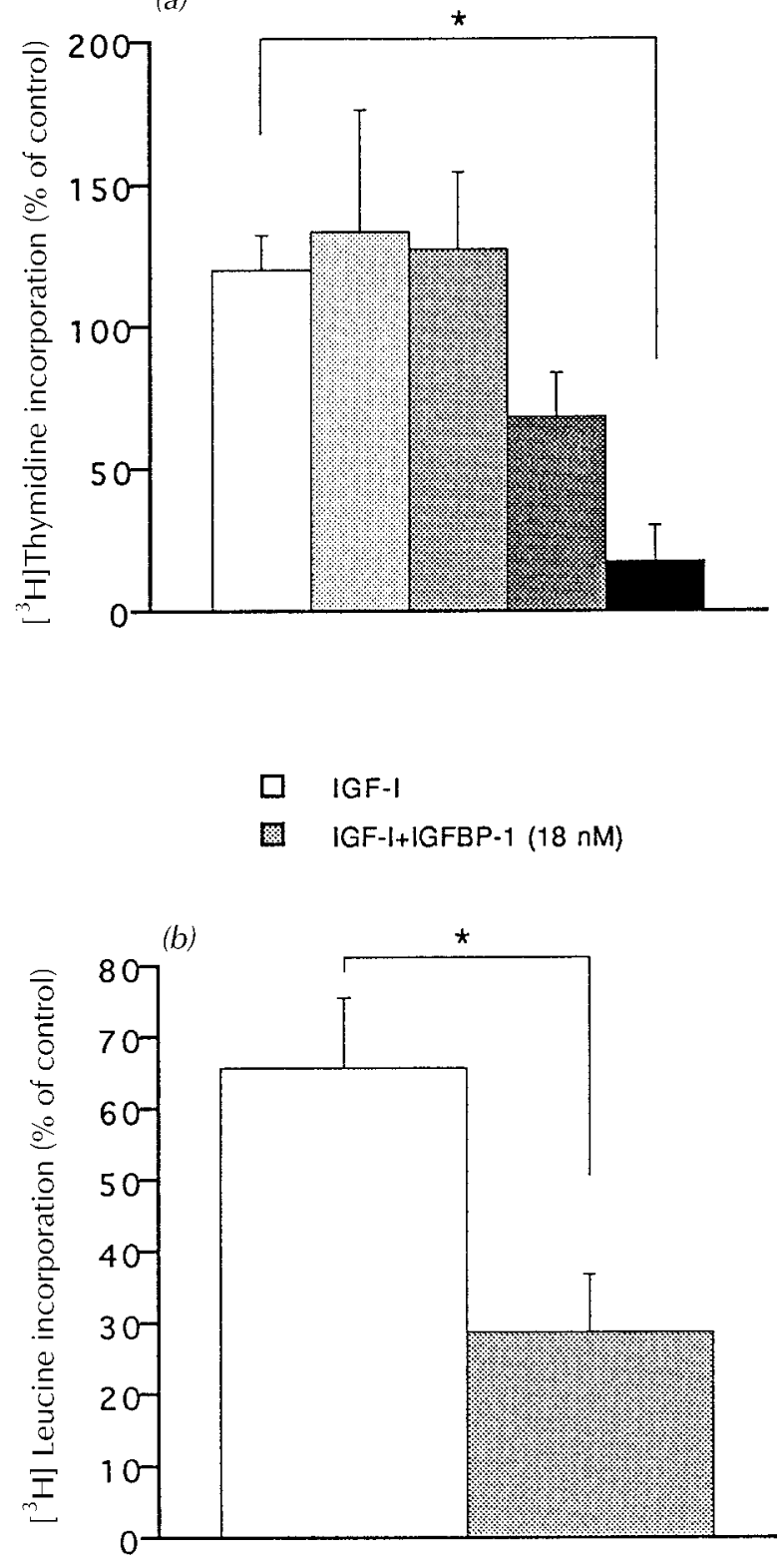

Figure 2 Modulation by IGFBP-1 of the response of rat vascular smooth muscle cells to IGF-I. (a) The effect of IGF-I added together with increasing concentrations of IGFBP-1 on

$\left[{ }^{3} \mathrm{H}\right]$ thymidine incorporation in rat VSMCs $(n=5)$. (b) The effect of IGFBP- 1 on IGF-I-induced $\left[{ }^{3} \mathrm{H}\right]$ leucine incorporation $(n=4)$. Values are given as means \pm S.E.M. ${ }^{*} P<0 \cdot 05$. Statistical comparison for more than two groups was made according to ANOVA Scheffé's test. Student's dependent $t$-test was used for two groups. The samples were measured in triplicate.
$18 \mathrm{nM} \quad(500 \mathrm{ng} / \mathrm{ml}) \quad$ IGFBP-4 $\quad\left(\mathrm{IC}_{50}=6 \cdot 2 \mathrm{nM}, n=4\right)$. IGFBP-4 at $18 \mathrm{nM}$ was also capable of significantly inhibiting the IGF-I effect on protein synthesis (Fig. 4b).

IGFBP-1, -2 and -4 mRNA levels in VSMCs

Confluent VSMCs were incubated for $48 \mathrm{~h}$ in serum-free F12 medium, with a change of medium after $24 \mathrm{~h}$. IGFBP-2 and IGFBP-4 mRNAs could be detected with solution hybridization, whereas IGFBP-1 mRNA was below the detection limit. The level of IGFBP-2 mRNA was just above the limit of detection and could be determined in 2 out of 3 samples, with an average value of $0.87 \mathrm{amol} / \mu \mathrm{g}$ DNA. The mRNA levels of IGFBP-4 were considerably higher, at $9 \cdot 6 \pm 1.9 \mathrm{amol} / \mu \mathrm{g}$ DNA $(n=3)$.

\section{Endogenous and exogenous IGFBP concentrations in the conditioned medium}

These experiments (see Fig. $5 a$ and $b$ ) were carried out in order to investigate whether exogenous IGFBP was degradated by the VSMCs and whether there were endogenously produced IGFBPs which could interact with exogenously added IGFBPs in modulating the IGF-I effect. Both exogenous IGFBP-2 and IGFBP-4 $(500 \mathrm{ng} / \mathrm{ml})$ in the conditioned medium were detected with heavy bands (at $32 \mathrm{kDa}$ and $26 \mathrm{kDa}$ respectively) with Western immunoblot. The bands were obvious throughout the studied time course, i.e. for up to $24 \mathrm{~h}$. The IGFBP bands in the conditioned medium were slightly weaker after $24 \mathrm{~h}$ in the presence of cells compared to control bands (exogenous IGFBPs in conditioned medium without cells). A faint immunoreactive band appeared for IGFBP-4 at $16 \mathrm{kDa}$, a possible degradation product. No endogenous IGFBP was detected and exogenous IGFBP added in a concentration of $5 \mathrm{ng} / \mathrm{ml}$ could not be detected.

To investigate whether IGFBP-2 and IGFBP-4 are secreted from the VSMCs at all, we collected and concentrated (1:20 times) conditioned medium. After $24 \mathrm{~h}$ incubation, we could detect an IGFBP-2 band at approximately $32 \mathrm{kDa}$ with Western blot (Fig. 6a). IGFBP-4 was detected at approximately $26 \mathrm{kDa}$ after $24 \mathrm{~h}$ incubation (Fig. 6b) and there was also a band at $16 \mathrm{kDa}$, probably an immunoreactive degradation product of IGFBP-4.

\section{Discussion}

In the present study we show that IGFBP-1, -2 and -4 all act in an inhibitory manner on IGF-I $(1 \mathrm{nM})$-induced DNA or protein synthesis in rat aortic smooth muscle cells (SMCs). The inhibitory effects differed between the different IGFBPs with IGFBP-1 being the most potent.

In our study IGFBP-1 was the most potent inhibitor of IGF-I-induced DNA synthesis $\left(\mathrm{IC}_{50}=1.6 \mathrm{nM}\right.$ or 


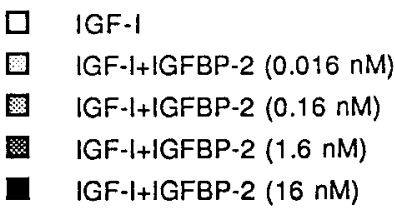

(a)

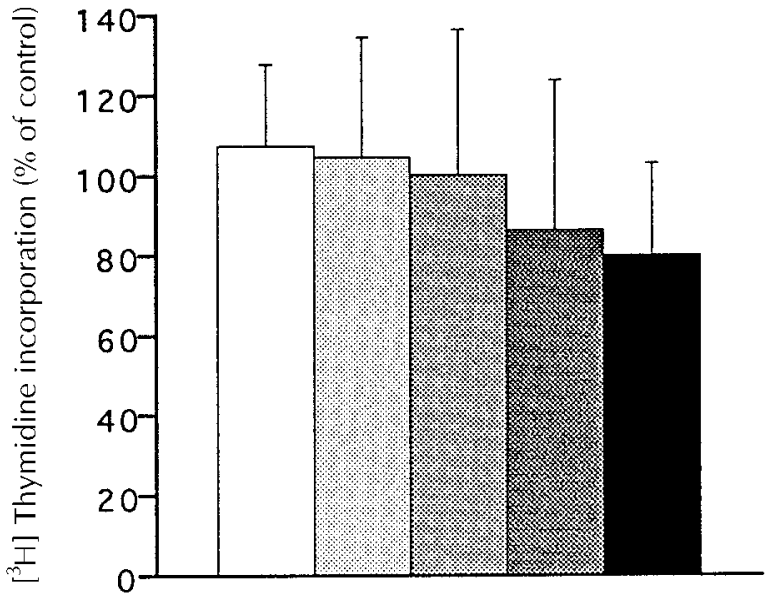

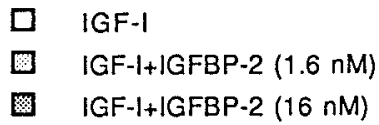

(b)

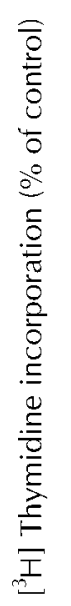

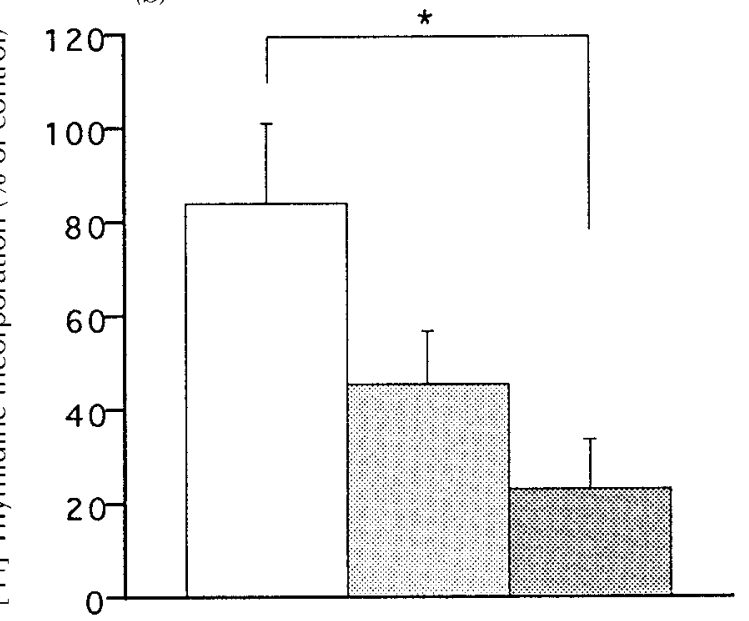

(c)

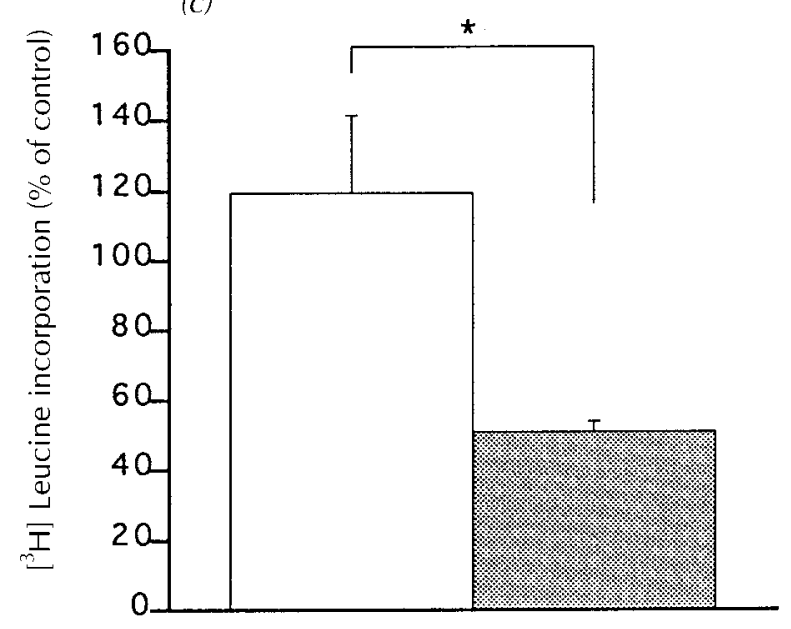

Figure 3 Modulation by IGFBP-2 of the response of rat vascular smooth muscle cells to IGF-I. (a) The effect of IGF-I added together with increasing concentrations of IGFBP-2 on $\left[{ }^{3} \mathrm{H}\right]$ thymidine incorporation in rat VSMCs $(n=5)$. (b) The effect of IGFBP-2 on IGF-I-induced $\left[{ }^{3} \mathrm{H}\right]$ thymidine incorporation $(n=3)$. In this case, IGFBP-2 and IGF-I were pre-incubated for $2 \mathrm{~h}$ at $4{ }^{\circ} \mathrm{C}$ prior to addition to the cells. (c) The effect of IGFBP-2 on IGF-I-induced $\left[{ }^{3} \mathrm{H}\right]$ leucine incorporation $(n=3)$. Values are means \pm S.E.M. ${ }^{*} P<0 \cdot 05$. Statistical comparison for more than two groups was made according to ANOVA Scheffé's test. Student's dependent $t$-test was used for two groups. The samples were measured in triplicate.

$44 \mathrm{ng} / \mathrm{ml})$. In addition, $18 \mathrm{nM}(500 \mathrm{ng} / \mathrm{ml})$ IGFBP-1 strongly inhibited IGF-I-induced protein synthesis. These results are in agreement with those of Motani et al. (1995).
In their experiments, however, IGF-I was pre-incubated with increasing concentrations of IGFBP-1 prior to addition to the rat aortic SMCs. An IGFBP-1 concentration 

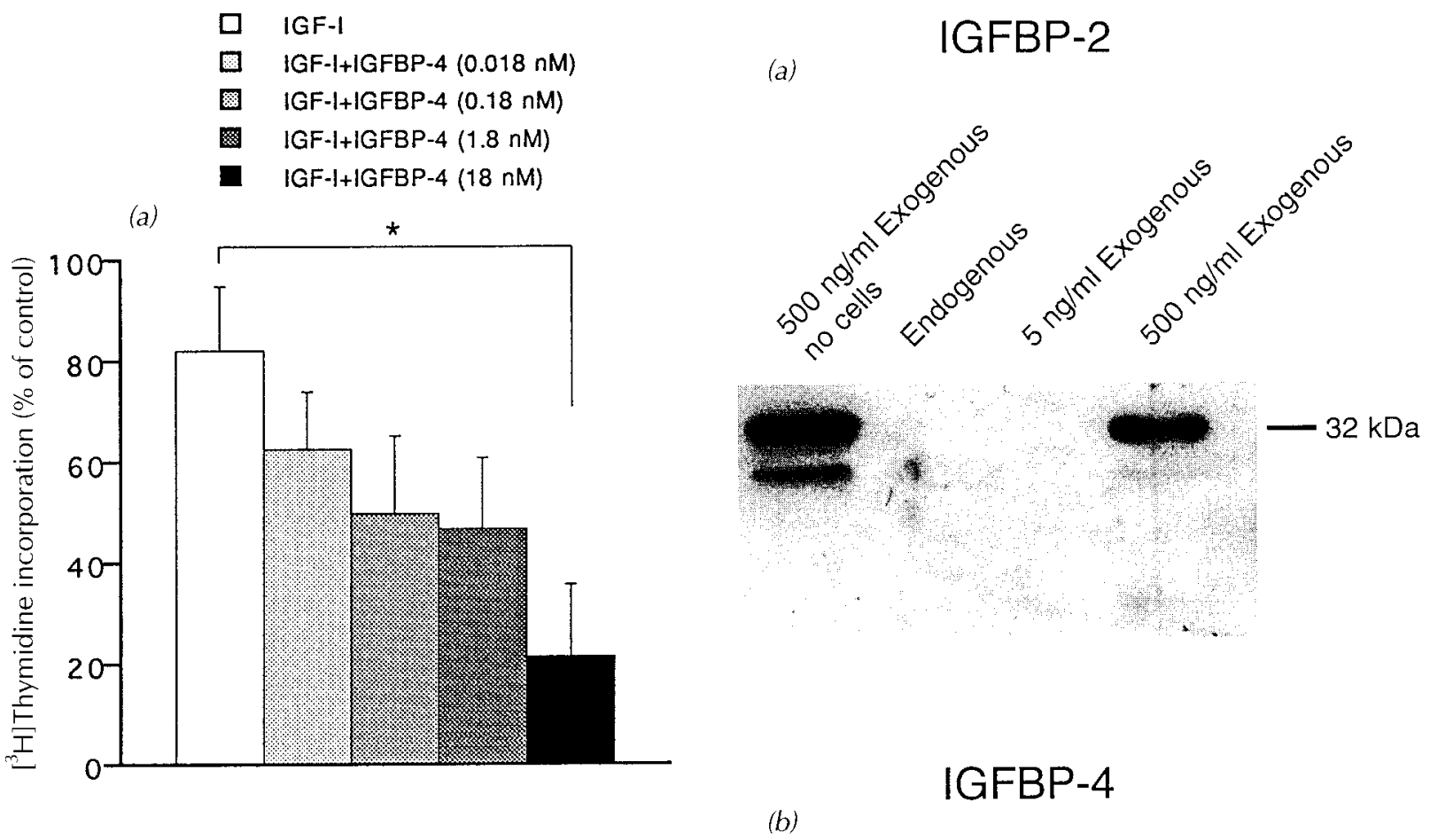

IGF-I

IGF-I+IGFBP-4 (18 nM)

(b)

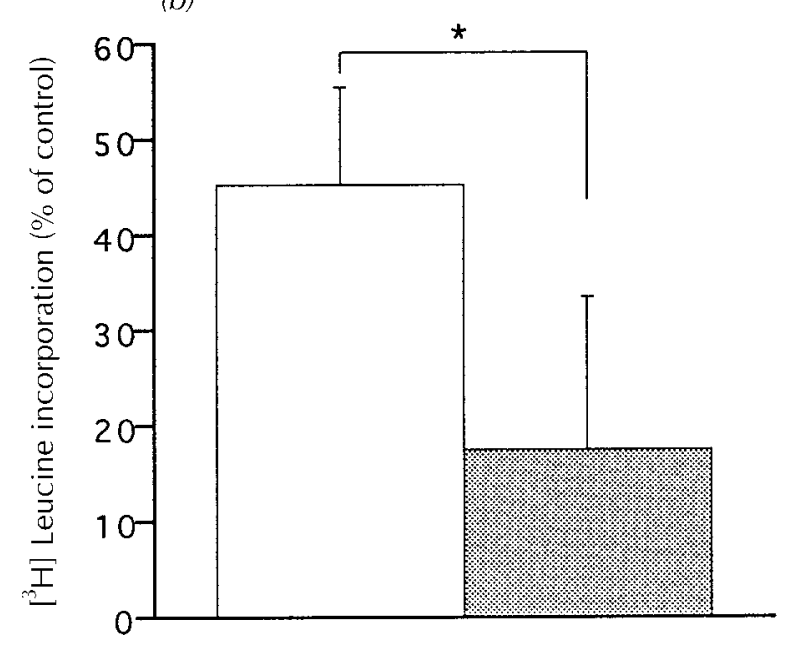

Figure 4 Modulation by IGFBP-4 of the response of rat vascular smooth muscle cells to IGF-I. (a) The effect of IGF-I added together with increasing concentrations of IGFBP-4 on $\left[{ }^{3} \mathrm{H}\right]$ thymidine incorporation in rat VSMCs $(n=4)$. (b) The effect of IGFBP-4 on IGF-I-induced $\left[{ }^{3} \mathrm{H}\right]$ leucine incorporation $(n=4)$. Values are means \pm S.E.M. ${ }^{*} P<0 \cdot 05$. Statistical comparison for more than two groups was made according to ANOVA Scheffé's test. Student's dependent $t$-test was used for two groups.
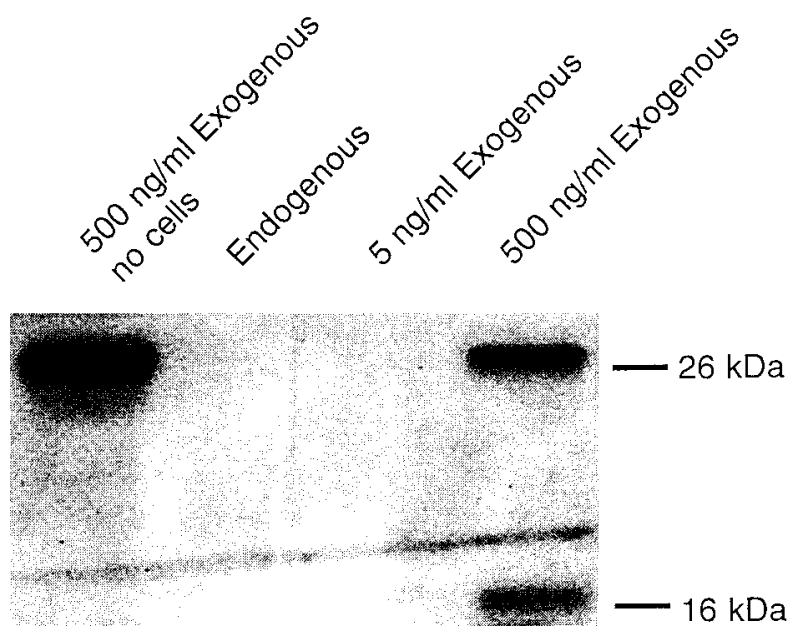

Figure 5 Levels of exogenous and endogenous IGFBP-2 and IGFBP-4 in conditioned medium (CM) of rat vascular smooth muscle cells. The cells were starved in 96-well plates for $24 \mathrm{~h}$ in F12 medium and were then incubated for another $24 \mathrm{~h}$ with or without the addition of exogenous IGFBP-2 (a) or IGFBP-4 (b). $\mathrm{CM}$ without cells served as control. The $\mathrm{CM}$ was collected and run onto a $15 \%$ SDS-PAGE. Western immunoblot was used to detect IGFBP-2 and IGFBP-4. The Figure shows representative blots $(n=3)$.

of $100 \mathrm{ng} / \mathrm{ml}$ was capable of neutralizing the effect induced by $4 \mathrm{nM}(30 \mathrm{ng} / \mathrm{ml})$ IGF-I. Busby et al. (1988) have shown that IGFBP-1 purified from amniotic fluid inhibited IGF-I-stimulated DNA synthesis in porcine SMCs. In contrast to this, Elgin et al. (1987) reported that 

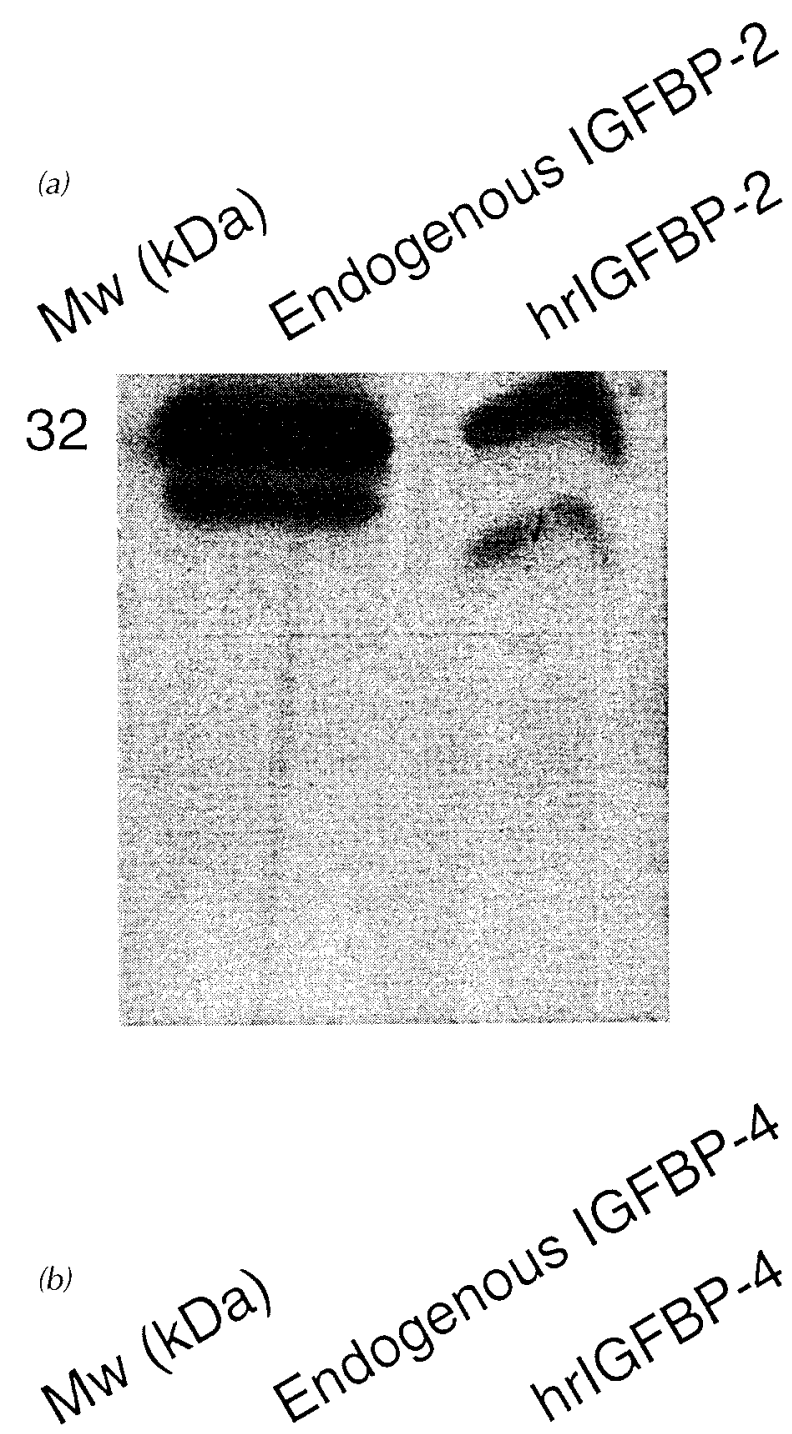

IGFBP-1, isolated from human amniotic fluid, potentiated the effect of IGF-I on DNA synthesis in porcine aortic SMCs, but only if platelet-poor plasma was included in the culture medium. IGFBP-1 at concentrations of 1000 and $10000 \mathrm{ng} / \mathrm{ml}$ has also been determined to inhibit IGF-I $(100 \mathrm{ng} / \mathrm{ml})$-induced migration of porcine aortic SMCs (Gockerman et al. 1995). In summary, our results as well as those of other groups show that IGFBP-1 inhibits IGF-I effects on cultured VSMCs in serum-free medium. The inhibitory action appears when the concentration of IGFBP-1 is about equimolar or higher than the IGF-I concentration.

IGFBP-2 (16 $\mathrm{nM}$ or $500 \mathrm{ng} / \mathrm{ml})$ pre-incubated with IGF-I for $2 \mathrm{~h}$ prior to addition to the rat VSMCs inhibited the effect of IGF-I on DNA and protein synthesis. IGFBP-2 was not capable of significantly inhibiting the effect of IGF-I without pre-incubation. Bourner et al. (1992) reported that bovine IGFBP-2 (5-20 ng/ml) potentiated IGF-I $(10 \mathrm{ng} / \mathrm{ml})$-induced DNA synthesis in porcine SMCs in the presence of platelet-poor plasma, but was an inhibitor in serum-free medium. It could be speculated that IGFBP-2 binds to the SMCs or extracellular matrix (McCusker et al. 1990, Hodgkinson et al. 1994) and thereby is not able to bind IGF-I.

IGFBP-4 significantly inhibited the response of rat VSMCs to IGF-I-induced DNA synthesis. The overall inhibitory effect of IGFBP-4 was not as potent $\left(\mathrm{IC}_{50}=6 \cdot 2\right.$ $\mathrm{nM}$ or $173 \mathrm{ng} / \mathrm{ml}$ ) as that of IGFBP-1. In agreement with the effect on DNA synthesis, $18 \mathrm{nM}(500 \mathrm{ng} / \mathrm{ml})$ IGFBP-4 also inhibited IGF-I-induced protein synthesis. In a study by Cohick et al. (1993), IGFBP-4 (50-250 $\mathrm{ng} / \mathrm{ml})$ had no effect on IGF-I $(20 \mathrm{ng} / \mathrm{ml})$-induced DNA synthesis in porcine SMCs, while $500 \mathrm{ng} / \mathrm{ml}$ IGFBP-4 gave a minimal decrease in the IGF-I response. It may thus be concluded that IGFBP-4 also has an inhibitory action on IGF-I effects in VSMCs.

The thermodynamic affinity of IGFBPs for IGF-I and the binding kinetics are the major determinants of how an IGFBP will modulate IGF activity. The affinity of the IGFBPs for IGF-I is about the same order of magnitude as the affinity of the type I IGF receptor for IGF-I (Arnqvist et al. 1995), which make them competitors for IGF-I. It should be mentioned that posttranslational modifications of IGFBPs, as occur following phosphorylation and glycosylation may influence their affinity for IGF-I (Jones et al. 1991, Rechler \& Clemmons 1998). In a study by Oh et al. (1993b), the affinities of IGFBP-1 to -4 for IGF-I were

Figure 6 Levels of endogenous IGFBP-2 and IGFBP-4 in concentrated conditioned medium of rat vascular smooth muscle cells. The cells were starved in Petri dishes for $24 \mathrm{~h}$ in serum-free F12 medium and were then incubated for another $24 \mathrm{~h}$ in fresh serum-free medium. The medium was collected, concentrated $(1: 20)$ and run onto a $15 \%$ SDS-PAGE. Western immunoblot was used to detect IGFBP-2 (a) and IGFBP-4 (b). The Figure shows representative blots $(n=3)$. hr, human recombinant. 
measured with the ${ }^{125} \mathrm{I}$ displacement technique and according to that study the affinities for IGF-I were: IGFBP-1 > IGFBP-4>IGFBP-2. The inhibitory actions of the IGFBPs found in the present study are in agreement with those results.

The physiological IGFBP-1 concentrations in the circulation of healthy individuals are in the range of 0-250 ng/ml (Brismar et al. 1994, Colett-Solberg \& Cohen 1996, Nyström et al. 1997), depending on the nutritional state. Physiological concentrations of IGFBP-2 and IGFBP-4 are higher, about $250 \mathrm{ng} / \mathrm{ml}$ in serum (Colett-Solberg \& Cohen 1996). This means that the circulating concentrations of IGFBP-1, -2 and -4 in vivo are in a similar range as used in the present study. The $\mathrm{IC}_{50}$ values determined for the IGFBPs on IGF-I action in our study suggest inhibitory actions of the IGFBPs at concentrations lower than $500 \mathrm{ng} / \mathrm{ml}$. Since the modulatory effects of the IGFBPs are dependent on the concentration ratio between IGFBPs and that of free IGF-I, physiological IGFBP concentrations may, therefore, inhibit IGF-I effects on VSMCs in vivo at free IGF-I concentrations of about $1 \mathrm{nM}$ or lower.

In the present study, we show that IGFBP-2 and -4 mRNAs, but not IGFBP-1 mRNA, are expressed in rat VSMCs. We found that endogenous IGFBP-2 and IGFBP-4 are secreted from rat VSMCs. IGFBP-4 production in rat VSMCs has previously been reported (Kamyar et al. 1994) and both IGFBP-2 and IGFBP-4 secretion has been shown for porcine VSMCs (Cohick et al. 1993). The fact that IGFBP-2 and -4 are expressed and secreted from VSMCs implies that the availability of IGFBP-2 and -4 in the vascular wall can be regulated by local synthesis. Both exogenous IGFBP-2 and IGFBP-4 were to a minor extent degraded by proteases in the presence of cells after $24 \mathrm{~h}$ incubation. This indicates that the difference in inhibitory action between IGFBP-2 and IGFBP-4 is not due to increased degradation of IGFBP-2.

In conclusion, IGFBP-1, -2 and -4 act in an inhibitory manner on IGF-I effects in vascular smooth muscle cells and have different potencies for inhibition of the IGF-I effects. The results suggest that these IGFBPs are capable of inhibiting IGF-I-induced effects at physiological concentrations.

\section{Acknowledgements}

We are grateful to Dr Mats Lake for kindly providing IGFBP-1. Financial support was obtained from the Swedish Medical Research Council (19x-4952), the Swedish Diabetes Association, Children's Diabetes Foundation and the Novo Nordisk Foundation.

\section{References}

Andress DL \& Birnbaum RS 1992 Human osteoblast-derived insulin-like growth factor (IGF) binding protein-5 stimulates osteoblast mitogenesis and potentiates IGF action. Journal of Biological Chemistry 267 22467-22472.

Arnqvist HJ, Bornfeldt KE, Chen Y \& Lindström T 1995 The insulin-like growth factor system in vascular smooth muscle: interaction with insulin and growth factors. Metabolism 44 58-66.

Bar RS, Booth BA, Bowes M \& Drake BL 1989 Insulin-like growth factor binding proteins from cultured endothelial cells: purification, characterization, and intrinsic biologic activities. Endocrinology 125 1910-1920.

Baxter R 1994 Insulin-like growth factor binding proteins in the human circulation - a review. Hormone Research 42 140-144.

Bourner MJ, Busby WH, Siegel NR, Krivi GG, McCusker RH \& Clemmons DR 1992 Cloning and sequence determination of bovine insulin-like growth factor binding protein-2 (IGFBP-2): comparison of its structural and functional properties with IGFBP-1. Journal of Cellular Biochemistry 48 215-226.

Brismar K, Fernqvist-Forbes E, Wahren J \& Hall K 1994 Effect of insulin on the hepatic production of insulin-like growth factor binding protein-1 (IGFBP-1), IGFBP-3, and IGF-I in insulindependent diabetes. Journal of Clinical Endocrinology and Metabolism 79 872-878.

Busby WH, Klapper DG \& Clemmons DR 1988 Purification of a 31000 dalton insulin-like growth factor binding protein from human amniotic fluid. Journal of Biological Chemistry 263 14203-14210.

Camacho-Hubner C, McCusker RH \& Clemmons DR 1991 Secretion and biological actions of insulin-like growth factor binding proteins in two human tumor-derived cell lines in vitro. Journal of Cellular Physiology 148 281-289.

Camacho-Hubner C, Busby WH Jr, McCusker RH, Wright G \& Clemmons DR 1992 Identification of the forms of insulin-like growth factor binding proteins produced by human fibroblasts and the mechanisms that regulate their secretion. Journal of Biological Chemistry 267 11949-11956.

Chen Y \& Arnqvist HJ 1994 Differential regulation of insulin-like growth factor binding protein-2 and -4 mRNA in muscle tissues and liver by diabetes or fasting. Journal of Endocrinology 143 235-242.

Chen Y, Bornfeldt KE, Arner A, Jennische E, Malmquist U, Uvelius B \& Arnqvist HJ 1994 Increase in insulin-like growth factor-I in hypertrophying smooth muscle. American Journal of Physiology 266 E224-E229.

Chen Y, Arner A, Bornfeldt KE, Uvelius B \& Arnqvist HJ 1995 Development of smooth muscle hypertrophy is closely associated with increased gene expression of insulin-like growth factor binding protein-2 and -4. Growth Regulation 5 45-52.

Cohick WS, Gockerman A \& Clemmons DR 1993 Vascular smooth muscle cells synthesize two forms of insulin-like growth factor binding proteins which are regulated differently by the insulin-like growth factors. Journal of Cellular Physiology 157 52-60.

Colett-Solberg PF \& Cohen P 1996 The role of the insulin-like growth factor binding proteins and the IGFBP proteases in modulating IGF action. Endocrinology and Metabolism Clinics of North America 25 591-615.

Cornell HJ, Embery G \& Herington AC 1986 Association of insulinlike growth factors with metabolically inactive and active carrier bound complexes in sera. Journal of Endocrinology 241 744-749.

Delafontaine P 1995 Insulin-like growth factor-I and its binding proteins in the cardiovascular system. Cardiovascular Research $\mathbf{3 0}$ 825-834.

DeMellow JSM \& Baxter RC 1988 Growth hormone dependent insulin-like growth factor binding protein both inhibits and potentiates IGF-I stimulated DNA synthesis in skin fibroblasts. Biochemical and Biophysical Research Communications 156 199-204.

Durnam DM \& Palmiter RD 1983 A practical approach for quantitating specific mRNAs by solution hybridization. Analytical Biochemistry 131 385-393. 
Elgin RG, Busby WH \& Clemmons DR 1987 An insulin-like growth factor binding protein enhances the biological response to IGF-I. Proceedings of the National Academy of Sciences of the USA $\mathbf{8 4}$ 3254-3258.

Gockerman A, Prevette T, Jones JI \& Clemmons DR 1995 Insulinlike growth factor (IGF)-binding proteins inhibit the smooth muscle cell migration responses to IGF-I and IGF-II. Endocrinology 136 4168-4173.

Hodgkinson SC, Napier JR, Spencer GSG \& Bass JJ 1994 Glycosaminoglycan binding characteristics of the insulin-like growth factor-binding proteins. Journal of Molecular Endocrinology 13 105-112.

Jones JI, D'Ercole AJ, Camacho-Hubner C \& Clemmons DR 1991 Phosphorylation of insulin-like growth factor binding protein-1 in cell culture in vivo: effects on affinity for IGF-I. Proceedings of the National Academy of Sciences of the USA 88 7481-7485.

Jones JI, Gockerman A, Busby WHJ, Camacho-Hubner C \& Clemmons DR 1993a Extracellular matrix contains insulin-like growth factor binding protein-5: potentiation of the effects of IGF-I. Journal of Cellular Biology 121 679-687.

Jones JI, Gockerman A, Busby WH, Wright G \& Clemmons DR 19936 Insulin-like growth factor binding protein 1 stimulates cell migration and binds to the $\alpha 5 \beta 1$ integrin by means of its Arg-Gly-Asp sequence. Proceedings of the National Academy of Sciences of the USA 90 10553-10557.

Kamyar A, Pirola CJ, Wang H-M, Sharifi B, Mohan S, Forrester JS \& Fagin JA 1994 Expression and insulin-like growth factor-dependent proteolysis of insulin-like growth factor-binding protein-4 are regulated by cell confluence in vascular smooth muscle cells. Circulation Research 74 576-585.

Kiefer MC, Schmid C, Waldvogel M, Schlapfer I, Futo E, Masiarz FR, Green K, Barr PJ \& Zapf J 1992 Characterization of recombinant human insulin-like growth factor binding proteins-4, -5 and -6 produced in yeast. Journal of Biological Chemistry 267 12692-12699.

Labarca C \& Paigen K 1980 A simple, rapid, and sensitive DNA assay procedure. Analytical Biochemistry 102 344-352.

Liu L, Delbe J, Blat C, Zapf J \& Harel L 1992 Insulin-like growth factor binding protein-3 (IGFBP-3), an inhibitor of serum growth factors other than IGF-I and -II. Journal of Cellular Physiology 153 15-21.

McCusker RH, Camacho-Hubner C, Bayne ML, Cascieri MA \& Clemmons DR 1990 Insulin-like growth factor (IGF) binding to human fibroblast and gliastoma cells: the modulating effect of cell released IGF binding proteins (IGFBPs). Joumal of Cellular Physiology 144 244-253.
Melton DA, Krieg PA, Rebagliati MR, Maniatis T, Zinn K \& Green MR 1984 Efficient in vitro synthesis of biologically active RNA and RNA hybridization probes from plasmids containing a bacteriophage SP6 promoter. Nucleic Acids Research 12 7035-7056.

Motani A, Rutherford C, Anggard EE \& Ferns GAA 1995 Insulinlike growth factor binding protein-1 inhibits arterial smooth muscle cell proliferation in vitro but does not reduce the neointimal response to balloon catheter injury. Atherosclerosis 118 57-66.

Nilsson J, Ksiazek T, Heldin C-H \& Thyberg J 1983 Demonstration of stimulatory effects of platelet-derived growth factor on cultivated rat arterial smooth muscle cells. Experimental Cell Research 14 231-237.

Nyström FH, Öhman KP, Ekman B, Österlund M, Karlberg BE \& Arnqvist HJ 1997 Population-based reference values for IGF-I and IGFBP-1: relations with metabolic factors anthropometric variables. European Journal of Endocrinology 136 165-172.

Oh Y, Müller HL, Lamson G \& Rosenfeld RG 1993a Insulin-like growth factor (IGF)-independent action of IGF-binding protein-3 in Hs578T human breast cancer cells. Journal of Biological Chemistry 268 14964-14971.

Oh Y, Müller HL, Lee D-Y, Fielder PJ \& Rosenfeld RG 19936 Characterization of the affinities of insulin-like growth factor (IGF)-binding proteins 1-4 for IGF-I, IGF-II, IGF-I/insulin hybrid, and IGF-I analogs. Endocrinology 132 1337-1344.

Rechler MM \& Clemmons DR 1998 Regulatory actions of insulinlike growth factor-binding proteins. Trends in Endocrinology and Metabolism 9 176-183.

Shimasaki S \& Ling N 1991 Identification and molecular characterization of insulin-like growth factor binding proteins (IGFBP-1, -2, -3, -4, -5 and -6). Progress in Growth Factor Research 3 243-266.

Skalli O, Ropraz P, Trzeciak A, Benzonana G, Gillssen D \& Gabbiani G 1986 A monoclonal antibody against $\alpha$-smooth muscle actin: a new probe for smooth muscle differentiation. Journal of Cellular Biology 103 2787-2796.

Spencer EM \& Chan K 1995 A 3-dimensional model for the insulinlike growth factor binding proteins (IGFBPs); supporting evidence using the structural determinants of the IGF binding site on IGFBP-3. Progress in Growth Factor Research 6 209-214.

Received 21 November 1997

Revised manuscript received 2 September 1998

Accepted 13 November 1998 